\title{
PERAN EKSISTENSI SAHAM DI LQ45 PADA KINERJA PROFITABILITAS PERUSAHAAN
}

\author{
Herman Karamoy \\ karamoy_herman@yahoo.com \\ Hizkia H. D. Tasik \\ Universitas Sam Ratulangi
}

\begin{abstract}
Many companies in Indonesia compete to improve the financial performance to be listed in LQ45 index. LQ45 index is the house of 45 stocks with high liquidity, big market capitalization and good financial performance. This paper aims to investigate whether the existence status of stocks in LQ45 index in the past affects the current profitability performance of the companies. This study relies on semesterly data from 19 companies dated from 2012 to 2015. The companies chosen have experienced to be listed in LQ45 at least once. ANTM stock is the only stock that has experienced both entering and exiting the $L Q 45$, while the rest have only experienced either entering or exiting the LQ45. The movement of the stock occurs every six months based on an evaluation of Indonesian Stock Exchange. Using panel data regression model of Net Profit Margin (NPM), the findings suggests that the existence of stocks in LQ45 index in previous period significantly affect the NPM. The results are robust and consistent across specifications either using fixed effect or random effect approaches. The magnitude ranges from 22,77 to 26,87 percentage points.
\end{abstract}

Key words: existence status; profitability; NPM; LQ45 index

\begin{abstract}
ABSTRAK
Banyak perusahaan di Indonesia berkompetisi untuk memperbaiki kinerja keuangan untuk bisa terdaftar di indeks LQ45. Indeks LQ45 adalah rumah bagi 45 saham dengan likuiditas yang tinggi, kapitalisasi pasar yang besar serta kinerja keuangan yang baik. Studi ini bertujuan untuk menginvestigasi apakah eksistensi saham di LQ45 di masa lampau mempengaruhi profitabillitas perusahaan saat ini. Penelitian ini menggunakan data semesteran dari 19 perusahaan yang ada di indeks LQ45 dari tahun 2012 sampai 2015. Ke-19 Perusahaan yang terpilih telah terdaftar dalam indeks LQ45 setidaknya satu kali. Saham ANTM adalah satu-satunya saham yang tercatat masuk dan keluar dalam indeks LQ45, berbeda dengan saham lainnya yang hanya tercatat masuk atau keluar dari indeks LQ45. Pergerakan dari saham terjadi setiap enam bulan sekali berdasarkan hasil evaluasi dari Bursa Efek Indonesia. Dengan menggunakan model regresi data panel, hasil penelitian ini menyarankan bahwa eksistensi di indeks LQ45 mempengaruhi Net Profit Margin (NPM) dengan besaran dampak berkisar 22,77 sampai 26,78 poin. Hasil ini robust dan konsisten di semua spesifikasi yang digunakan.
\end{abstract}

Kata kunci: status eksistensi; profitabilitas; NPM; indeks LQ45

\section{PENDAHULUAN}

Dengan berkembangnya ekonomi dan perdagangan, masyarakat memiliki makin banyak pilihan untuk mengalokasikan dananya baik investasi fisik maupun digital. Investasi fisik dapat berupa tanah, properti, tabungan, valuta asing atau saham yang dapat dijadikan pilihan yang dapat dipertimbangkan. Investasi digital dapat berupa crypto currency, mobile application, dan sebagainya. Pemilihan saham untuk investasi dibutuhkan pengetahuan yang cukup atas kinerja perusahaan maupun perkembangan saham di pasar. Investasi merupakan 
penempatan sejumlah dana pada saat ini dengan harapan akan ada imbalan di masa mendatang. Imbalan yang ada pada era digital ini sudah semakin bervariasi dengan rate of return yang juga makin bervariasi. Jika tanah hanya memberikan imbalan yang kecil tapi stabil, saham dapat memiliki imbalan yang sangat besar namun tidak stabil sehingga dibutuhkan kemampuan untuk dapat membaca perkembangan harga dari saham tersebut. Harga saham merupakan salah satu penentu pemilihan saham yang akan dibeli masyarakat. Namun, status saham di bursa saham, sebagai contoh, di indeks LQ45 juga dapat mempengaruhi keputusan calon investor untuk membeli saham tersebut. Hal ini disebabkan oleh keyakinan masyarakat terhadap saham yang ada di LQ45 di mana saham-saham ini memiliki kekuatan finansial yang lebih baik dari saham-saham yang ada di luar LQ45. Saham terindeks LQ45 biasanya disebut saham blue-chips. Keyakinan ini tidak lepas dari persepsi risiko yang dimiliki oleh masyarakat di mana saham yang ada di LQ45 memiliki risiko yang lebih kecil dibanding dengan saham yang ada di luar LQ45.

Indeks LQ45 merupakan indeks atas kumpulan saham dengan tingkat likuiditas yang baik dan dapat menjadi acuan baik bagi investor, pedagang, broker, maupun analis saham untuk melihat perkembangan saham dan pasar. Indeks LQ45 dapat menjadi proxi bagi IHSG karena korelasi indeks LQ45 dengan IHSG sangat tinggi, yaitu 99,99 persen. Indeks LQ45 sangat mempengaruhi IHSG karena saham yang tercatat pada indeks LQ45 merupakan saham dengan nilai kapitalisasi pasar yang besar, sehingga pergerakannya dapat mempengaruhi pergerakan IHSG. Sebagian masyarakat akan merasa lebih tenang dengan menginvestasikan dananya di saham yang terdapat di LQ45 dibanding dengan saham yang berada di luar LQ45. Pemilihan saham tersebut akan mendorong peningkatan volume perdagangan lalu meningkatkan harga saham yang selanjutnya meningkatkan kapitalisasi pasar.
Eksistensi saham di LQ45 sangat dipengaruhi oleh faktor eksternal dan internal (Prasetya dan Tasik (2017). Penelitian terdahulu menemukan hubungan antara faktor eksternal dengan indikator keuangan saham. Tandelilin (2010) menemukan bahwa suku bunga dan harga saham memiliki hubungan negatif. Suku bunga yang tinggi dapat mempengaruhi nilai sekarang atau present value dari aliran kas perusahaan. Hal ini akan membuat pilihan investasi yang lain menjadi tidak menarik lagi. Di lain pihak, suku bunga yang tinggi juga akan meningkatkan biaya modal perusahaan. Selain suku bunga, inflasi juga merupakan faktor eksternal yang dapat mempengaruhi harga saham. Tingkat inflasi yang tinggi biasanya dikaitkan de ngan kondisi ekonomi yang terlalu panas dimana permintaan atas produk melebihi penawaran yang ada. Hal ini akan menyebabkan penurunan daya beli masyarakat. Prasetya dan Tasik (2017) menemukan bahwa faktor eksternal seperti Produk Domestik Bruto (PDB) tidak mempengaruhi keberadaan saham untuk masuk di LQ45. Faktor internal seperti kapitalisasi pasar dan Return On Asset (ROA) juga tidak mempengaruhinya. Volume perdagangan merupakan satusatunya faktor internal yang mempengaruhi masuk tidaknya suatu saham di LQ45. Bursa Efek Indonesia (BEI) menetapkan kriteriakriteria saham untuk dapat masuk dalam indeks LQ45, yaitu masuk dalam peringkat 60 besar dalam 12 bulan terakhir, dengan melihat nilai transaksi atau volume perdagangan; memiliki ranking terbesar berdasarkan rata-rata kapitalisasi pasar selama 12 bulan terakhir; dan telah terdaftar di BEI minimal 3 bulan terakhir.

Jika suatu saham terdaftar pada LQ45, sangat diharapkan bahwa kinerja keuangan dari perusahaan menjadi lebih baik, produktif dan profitable. Sayangnya, menurut pengetahuan kami, belum ada studi yang mencoba melihat hubungan antara status eksistensi saham di LQ45 dengan indikator profitabilitas perusahaan. Studi ini mencoba menginvestigasi hubungan dari kedua variabel ini dengan mengontrol beberapa 
indikator keuangan yang ada. Diharapkan studi ini dapat membantu dalam formulasi kebijakan apakah perlu ada keseragaman regulasi bagi perusahaan dengan saham yang terdaftar pada LQ45 dengan perusahaan yang sahamnya tidak terdaftar, khususnya terkait dengan usaha menjaga kestabilan kinerja keuangan perusahaan.

\section{TINJAUAN TEORETIS}

Dalam melakukan investasi, suatu portfolio yang baik sangat diperlukan sebab dalam pengambilan keputusan mengenai portfolio apa yang akan dipilih membutuhkan informasi pendukung yang baik pula, misalnya tingkat imbalan dan risiko (contohnya, standar deviasi). Tanpa mempertimbangkan risiko yang ada, maka keputusan yang diambil dapat memiliki risiko yang tinggi (Suryani dan Herianti, 2015). Berbagai tes dibutuhkan untuk melihat apakah portfolio yang diambil memiliki kinerja yang baik. Selain mengukur tingkat imbalannya, risiko juga perlu diukur dengan baik (Jogiyanto, 2010). Pilihan investasi saat ini sudah menjadi semakin majemuk. Berbagai penulis mencoba mengembangkan berbagai metode dalam melakukan investasi yang menguntungkan, mulai dari investasi properti atau real estate (Waller dan Wright, 2019), investasi crypto currency (Danial, 2019), investasi saham (Malkiel, 2019), dan sebagainya. Dalam investasi saham, masyarakat ditawarkan dengan berbagai pilihan mulai dari pilihan pasar sekunder hingga pilihan saham berdasarkan berbagai pertimbangan dan fitur yang ditawarkan oleh pasr sekunder. Sebagai contoh masyarakat Indonesia dapat memilih saham di pasar sekunder seperti ke National Association of Securities Dealers Automated Quotations (Nasdaq) di Amerika Serikat.

Chung et al. (1996) mengemukakan bahwa pasar sekunder ada untuk perdagangan berbagai sekuritas. Masing-masing pasar sekunder memiliki fitur yang membedakan pasar satu dengan lainnya. New York Stock Exchange (NYSE) dan American Stock Exchange (AMEX) adalah dua pasar yang juga berada di Amerika Serikat yang memiliki marketplace fisik untuk perdagangan sekuritas. Keduanya memiliki limit orders yang membuat anggota pasar yang lain meninggalkan mereka dan bertindak sebagai dealer di saham-saham tertentu.

Di lain pihak, Kandel dan Marx (1997) menjelaskan bahwa pasar Nasdaq memiliki fitur institusional yang membuatnya berbeda dari pasar lainnya termasuk Bursa Efek Indonesia (BEI). Salah satu yang membedakan adalah adanya minimum tick size yang tetap yang relatif lebih besar dibandingkan dengan harga relevannya, tidak memiliki limit orders yang mengikat, adanya metode alternatif yang dapat menarik order flow, serta adanya batasan pada sebaran. Hal yang paling membedakan dengan NYSE adalah NYSE memiliki limit orders yang mengikat. Demsetz (1997) juga mengangkat isu ini di mana limit orders ini merupakan fitur NYSE dan dimasukkan dalam kuota untuk menentukan bid terbaik yang tersedia serta kuota ask. Sedangkan pasar Nasdaq, limit order dikelola secara terpisah oleh dealer dan adalah bagian terpisah dari pengkuotaan pasar oleh dealer yang lain. Schwert (1997) menambahkan bahwa nilai kuota yang ditampilkan harus mencerminkan kemampuan dealer untuk membeli atau menjual pada kuota yang ditampilkan, sehingga mereka harus menutupi biaya pembuatan pasar.

Goff (1994) berargumen bahwa, berbeda dengan data NYSE dan AMEX, data Nasdaq memungkinkan untuk dilakukan pemeriksaan hubungan antara anomali. Yaitu dengan cara memeriksa perusahaan yang jauh lebih kecil dari yang diperiksa dalam penelitian sebelumnya. Selain itu, karakteristik dari perusahaan kecil di NYSE dan AMEX berbeda dari karakteristik perusahaan kecil di Nasdaq. Perusahaan kecil di NYSE dan AMEX sering berukuran kecil karena kinerja masa lalu yang buruk sementara banyak perusahaan kecil di Nasdaq itu kecil karena kriteria inklusi minimal Nasdaq dibandingkan dengan NYSE dan AMEX. Selain itu, terdapat juga perbedaan dalam 
struktur mikro dari pasar NYSE dan AMEX dan struktur mikro dari pasar Nasdaq. Perusahaan NYSE dan AMEX diperdagangkan melalui sistem di mana seorang spesialis tunggal membuat pasar dalam suatu saham. Sedangkan perusahaan Nasdaq diperdagangkan melalui sistem yang memungkinkan banyak pembuat pasar. Perbedaan ini menunjukkan bahwa hubungan antara anomali mungkin berbeda antara perusahaan Nasdaq dan perusahaan NYSE atau AMEX. Jika hubungan berbeda, perbedaan ini dapat memberikan informasi tambahan untuk digunakan dalam mencari penyebab anomali. Goff menemukan bahwa hubungan antara anomali tidak sama untuk perusahaan Nasdaq seperti untuk perusahaan NYSE dan AMEX. Dengan demikian, temuan dan kesimpulan studi yang didasarkan pada data NYSE dan AMEX mungkin tidak berlaku untuk perusahaan Nasdaq, sehingga pemilihan antara satu pasar sekunder dengan pasar sekunder lainnya harus dipertimbangkan berdasarkan fitur yang ada pada pasar itu.

Chung dan Hradzdil (2010) juga menambahkan beberapa poin dalam membedakan NYSE, AMEX dan Nasdaq dalam terkait isu likuiditas. Perbedaan yang mencolok lainnya adalah aturan perdagangan dan mekanisme penetapan harga pembukaan yang berperan dalam sejauh mana likuiditas terkait dengan efisiensi pasar. Di satu sisi, NYSE dan AMEX didorong oleh pesanan pasar lelang (dengan dealer monopolistik dan spesialis), Nasdaq adalah pasar multi-dealer yang lebih kompetitif. Selain dari akun mereka sendiri, spesialis memfasilitasi perdagangan melalui limit order yang menyediakan komponen besar likuiditas di NYSE atau AMEX, sedangkan pada Nasdaq, tanpa buku pesanan batas pusat, dealer terus-menerus memposting penawaran perusahaan dan meminta penawaran pada layar elektronik. Dealer Nasdaq, di sisi lain, tidak bergantung pada limit order investor dan harus mengirim penawaran harga untuk setidaknya 1.000 saham. Bahkan dengan tidak adanya perdagangan, dealer
Nasdaq memiliki insentif untuk merevisi kuotasi mereka mengikuti rilis berita terkait harga; jika tidak, mereka rentan terhadap pedagang lain. Hasil penelitian Chung dan Hrazdil mengkonfirmasi bahwa peningkatan likuiditas meningkatkan efisiensi pasar, dan menunjukkan bahwa efek ini diperkuat selama periode dengan informasi baru. Setelah mengendalikan efek likuiditas dan informasi, perusahaan Nasdaq mengalami peningkatan efisiensi pasar. Mereka juga mengkonfirmasi bahwa simpulan efisiensi pasar tidak seragam di berbagai portofolio yang dibentuk berdasarkan frekuensi perdagangan, volume dan kapitalisasi pasar.

Karena adanya sejumlah perbedaan antara satu pasar dengan pasar lain, maka perpindahan antar pasar pun tidak bisa terelakkan. Dang et al. (2018) menjelaskan bahwa perpindahan dari pasar sekunder satu ke yang lain sangat mungkin terjadi. Perpindahan sukarela pertama dari NYSE ke Nasdaq adalah yang dilakukan oleh Aeroflex Corporation pada tahun 2000. Sebelum tahun 2000, perusahaan pindah ke NYSE seolah-olah karena memiliki persyaratan daftar yang lebih ketat, dan karena langkah tersebut dapat dianggap sebagai sinyal peningkatan kualitas perusahaan. Di sisi lain, alasan untuk pindah ke Nasdaq belum dipahami dengan baik. Tidak ada bukti empiris yang jelas tentang bagaimana likuiditas dipengaruhi ketika perusahaan pertama pindah dari NYSE ke Nasdaq. Setiap kali dilakukan perpindahan dari satu pasar ke pasar lainnya, perusahaan harus mengalami biaya yang mahal. Namun biaya perpindahan tersebut tidak sebanding dengan pemghematan yang didapatkan atas biaya perdagangan yang dikenakan suatu pasar sehingga dapat meningkatkan likuiditas. Alasan lain yang disebutkan termasuk peningkatan volume perdagangan yang diharapkan dan peningkatan visibilitas perusahaan. Ada beberapa kemungkinan penjelasan yang mendasari alasan yang dinyatakan secara publik untuk beralih tempat listing saham. Yang pertama adalah mengambil keuntungan dengan ukuran yang 
relatif besar dari perusahaan yang berpindah ke Nasdaq, yang didominasi oleh perusahaan kecil. Peningkatan visibilitas ini dapat membantu menghilangkan perbedaan dalam likuiditas di kedua bursa efek dan meningkatkan volume perdagangan. Selain itu, Nasdaq dianggap lebih berfokus pada teknologi, dan karena itu terdaftar di bursa dapat mengubah persepsi perusahaan oleh asosiasi.

Dang et al. (2018) menemukan bahwa perpindahan ke Nasdaq meningkatkan biaya perdagangan, meningkatkan visibilitas, menarik lebih banyak penyedia likuiditas dalam jangka panjang, mendukung kenaikan volume perdagangan berikutnya. Hasil mereka menunjukkan bahwa aspek multi-dimensi mungkin menjadi pertimbangan penting dalam perpindahan antar bursa.

Hal ini dibenarkan oleh Carrion (2013) di mana adanya perdagangan dengan frekuensi yang tinggi (HFT) di pasar Nasdaq sebagai akibat dari partisipasi perdagangan yang menyebabkan spread menjadi lebih lebar saat HFT menyediakan likuiditas atau menjadi lebih sempit saat HFT menarik likuiditas. Hal ini berbeda dengan Indeks Harga Saham Gabungan (IHSG) dari Bursa Efek Indonesia atau yang disebut dengan IDX composite indeks. IDX (2018) menyebutkan pada IDX Fact Book bahwa bertransaksi di IDX didasarkan pada sistem pasar berbasis order di mana ada batasan order yang ditentukan per hari atau sesi. Pedagang dapat membeli dan menjual sekuritas dengan menggunakan nama mereka sebagai bagian dari portofolio investasi. Sistem perdagangan akan mengecek atau memvalidasi halhal di bawah ini pada masukan order dan menambahkannya sebelum menerima dan submit order:

1. Price step dan pergerakan harga maximum

2. Batasan harga minimum

3. Harga dan volume penolakan otomatis

4. Batasan perdagangan cash

Untuk menjamin keamanan dan ketersediaan, perdagangan remote didukung oleh suatu link yang disiapkan khusus. Beberapa hal yang dilakukan pada IDX adalah adanya sesi pre-opening, pre-closing dan post-opening. Beberapa karakteristik dari sesi pre-opening, yaitu:

1. Sesi ini mengijinkan anggota IDX untuk menjual dan membeli order sesuai dengan ketersedian stok, step value dan batasan penolakan otomatis.

2. Saham diperdagangkan pada sesi ini dapat berupa saham yang termasuk pada indeks LQ45 dan saham lainnya yang ditentukan berdasarkan kebijakan perdagangan

3. Harga yang ditawarkan berdasarkan harga sebelumnya

4. Order book tidak bisa dilihat

5. Sedangkan beberapa karakteristik sesi pre-closing adalah:

6. Sesi ini mengijinkan anggota IDX untuk menjual dan membeli order sesuai dengan ketersedian stok, step value dan batasan penolakan otomatis.

7. Order baru yang masuk ke IDX pada sesi ini tidak didistribusi pada pelanggan datafeed.

8. Saham-saham yang diperdagangkan pada sesi ini adalah saham yang dikeluarkan dari hak dan warrant.

9. Harga yang ditawarkan berdasarkan harga sebelumnya atau harga pembukaan.

10.Matching process menggunakan call auction mechanism

11.Beberapa karakteristik dari sesi posttrading adalah:

12.Anggota IDX dapat menjual dan membeli order pada harga penutupan

13.Perubahan pada harga penjualan atau pembelian hanya dapat dilakukan pada harga penutupan

14.Saham-saham yang diperdagangkan pada sesi ini adalah saham-saham yang dikeluarkan dari hak dan warrant.

15.IDX juga memfasilitasi perdagangan saham lewat negosiasi antara pembeli dan penjual. Pada pasar negosiasi, perdagangan dilaksanakan lewat prosess individual bid (negosiasi langsung) antara 
anggota IDX, investor, antara investor maupun antara enggota IDX dan investor. Aturan untuk pasar negosiasi adalah:

1. Saham-saham diperdagangkan dengan menggunakan unit per lembar.

2. Price fraction tidak berlaku, tapi direkomendasikan untuk menggunakan harga saham pada pasar reguler sebagai referensi

3. Transaksi yang cocok tidak akan mempengaruhi perhitungan indeks sebab transaksi itu dilakukan pada pasar reguler.

4. Tanggal settlement didasarkan pada kesepakatan antara penjual dan pembeli, jika tidak terjadi kesepakatan, maka harus mengikuti aturan $\mathrm{T}+2$.

Setiap awal bulan, IDX merilis daftar saham yang layak untuk penjualan marjin dan singkat di bawah kriteria yang mempertimbangkan likuiditas dan kinerja keuangan perusahaan. Kriteria yang digunakan adalah:

1. Jika saham sudah didaftarkan di IDX setidaknya 12 bulan, maka saham itu harus diperdagangkan setidaknya 90 persen dari total hari perdagangan selama 6 bulan dan diperdagangkan pada pasar reguler dengan nilai perdagangan harian rata-rata lebih dari 5 miliar rupiah selama 6 bulan terakhir, nilai perdagangan harian rata-rata lebih dari 250 juta dan volume lebih dari 500 ribu lembar saham pada 6 bulan terakhir.

2. Jika saham didaftarkan pada IDX selama 3 sampai 12 bulan, maka saham itu harus diperdagangkan setidaknya 90 persen dari total hari perdagangan untuk 3 bulan terakhir jika terdaftar kurang dari 6 bulan atau 6 bulan jika sudah terdaftar lebih dari 6 bulan.

Apapun jenis investasi yang dipilih, risiko selalu ada. Risiko yang ada harus dipelajari dengan baik untuk menghindari kerugian yang kemudian menekan tingkat imbalan, misalnya dengan menggunakan analisa korelasi atau Bayesian (Miller, 2018). Untuk menghindari risiko yang tinggi atau yang tidak pasti, masyarakat lebih memilih saham-saham blue-chips dibanding dengan saham-saham non blue-chips. Menurut Srivastava dan Sheikh (2016) mengungkapkan bahwa saham-saham blue-chips dianggap sebagai saham dengan nilai yang tinggi untuk investasi jangka panjang. Biasanya saham-saham ini memiliki pertumbuhan yang baik di jangka panjang karena perusahaannya memiliki reputasi yang baik khususnya dalam hal pendapatan yang stabil. Jika terjadi kelesuan ekonomi, para investor memilih saham-saham ini sebagai tempat pelarian karena keamanan yang dimiliki oleh saham-saham ini.

Naik turunnya kinerja suatu saham dipengaruhi oleh banyak faktor dan hubungan antara faktor-faktor yang dapat menggerakkan pasar-pasar keuangan masih merupakan suatu misteri. Sehingga dibutuhkan data time series yang cukup panjang untuk dapat memahami hubungan dari pasarpasar ini. Salah satu manfaat dengan menggunakan data time series yang panjang adalah dapat menemukan keterkaitan antara pasar sebelum terjadinya suatu kejadian, misalnya krisis keuangan 2008, dengan pasar setelah krisis keuangan. Data yang baik biasanya tersedia jika saham-saham yang dipilih adalah blue-chips (Guedes et al., 2017).

Selain bermanfaat bagi masyarakat dalam pengambilan keputusan investasi, indeks dari saham-saham blue-chips ini juga dipakai sebagai cerminan kinerja indeks saham gabungan suatu negara. Annaert et al. (2011) menggunakan indeks saham bluechips sebagai proxi indeks pasar seluruh saham yang tercatat pada Brussels Stock Exchange dengan menggunakan data 1833 2005. Mereka menemukan bahwa indeks saham blue-chips dapat menangkap fakta dari imbalan berbobot nilai dari seluruh saham yang terdaftar pada Brussels Stock Exchange pada periode tersebut.

Indeks saham blue-chips di dunia meliputi LQ 45, DJIA, S dan P 500, S dan P 400, Nasdaq 100, Russell 2000 ETFs dan masih banyak lagi. Ivanov et al. (2013) mempelajari perilaku price discovery dari beberapa indeks saham blue-chips termasuk DJIA, S dan P 500, 
S dan P 400, Nasdaq 100, dan Russell 2000 ETFs. Mereka menilai bahwa terjadi tren yang meningkat pada metriks perdagangan price discovery dari semua indeks kecuali DJIA. Hal ini lebih disebabkan oleh pasar spot bukan karena future market yang mendorong price discovery. Hal ini karena ketertarikan investor yang kemudian mendorong adanya proses arbitrage yang kemudian mendorong harga-harga dari dana yang diperdagangkan sama dengan nilai net assets yang muncul untuk mempromosikan spot market price discovery. Di Indonesia, saham-saham blue-chips ini dikenal dalam indeks LQ45. Laman IDX mendefinisikan indeks LQ45 adalah indeks yang mengukur performa harga dari 45 saham-saham yang memiliki likuiditas tinggi dan kapitalisasi pasar besar serta didukung oleh fundamental perusahaan yang baik. (Definisi ini diambil dari laman resmi IDX yang diakses pada 15 Agustus 2019 melalui alamat: https://www.idx.co.id/produk/indeks).

Laman Wikipedia mencatat bahwa Bursa Efek Indonesia mendefinisikan LQ 45 sebagai indeks dari 45 perusahaan yang termasuk dalam 60 perusahaan dengan kapitalisasi pasar tertinggi dalam 1-2 bulan terakhir, 60 perusahaan dengan nilai transaksi tertinggi di pasar reguler dalam 12 bulan terakhir, telah tercatat di Bursa Efek Indonesia selama minmal 3 bulan, memiliki kondisi keuangan, prospek pertumbuhan dan nilai transaksi yang tinggi. Indeks LQ 45 dihitung setiap enam bulan oleh divisi penelitian dan pengembangan Bursa Efek Indonesia. (Materi diambil dari laman Wikipedia yang diakses pada 16 Agustus 2019 lewat link: https:// id.wikipedia.org/wiki/ Indeks_LQ 45). IDX (2018) menjelaskan, hingga saat ini, indeks LQ45 meliputi setidaknya 70 persen kapitalisasi pasar saham dan nilai transaksi pada pasar reguler. Tanggal perhitungan yang dijadikan dasar adalah 13 Juli 1994 dengan basis nilai 100 . Beberapa faktor yang dapat membuat saham masuk ke LQ45 adalah:

1. Saham-saham harus didaftarkan pada IDX setidaknya 3 bulan
2. Kinerja saham di pasar reguler adalah nilai perdagangan, volume dan frekuensi transaksi

3. Jumah hari perdagangan pada pasar reguler

4. Kapitasilasi pasar saham pada periode tertentu

5. Di samping faktor likuiditas dan kapitalisasi pasar, pemilihan sahamsaham LQ45 didasarkan pada kondisi keuangan dan prospek pertumbuhan perusahaan-perusahaanya

Menurut definisi, keberadaan saham di LQ45 sangat bergantung pada likuiditas dan kapitalisasi. Meskipun begitu, Prasetya dan Tasik (2017) menemukan bahwa, dengan menggunakan data semesteran dari 2012 hingga 2015, kapitalisasi pasar tidak signifikan mempengaruhi keberadaan saham di LQ45. Volume perdagangan merupakan satu-satunya faktor internal yang mempengaruhi masuk tidaknya suatu saham di LQ45. Volume perdagangan yang tinggi berasosiasi dengan tingginya kecenderungan saham tersebut untuk berada dan berada di LQ45.

Dengan masuknya suatu saham di indeks LQ45, kinerja perusahaan idealnya dijaga dengan baik untuk dapat bertahan di LQ45 dan menjadi saham pilihan masyarakat. Namun, filosofi reversal of fortune terkadang masih berlaku. Banyak saham blue-chips di dunia mengalami kegagalan meskipun tadinya memiliki kinerja yang baik. Poon (2016) mengemukakan bahwa saham blue-chips pun tidak lepas dari kejatuhan, misalnya saham Swiber, Noble Group, Nokia, Lehman Brothers, dan Deutsche Bank. Hal yang sama juga terjadi pada General Electric di tahun 2018 (Bromels, 2018).

Goff (1994) mengemukakan bahwa terdapat banyak studi yang mendokumentasikan anomali stock return dan hubungan terbalik antara risk-adjusted returns dan ukuran perusahaan atau harga saham. Hasil studi menunjukkan bahwa terdapat hubungan langsung antara risk-adjusted returns dan earnings-price ratio (E/P). Hasil penelitian 
ini menyarankan bahwa ada kemungkinan pasar sekuritas menjadi tidak efisien atau model penetapan harga aset tradisional yang digunakan untuk menyesuaikan risiko menjadi misspecified. Inilah yang dapat memungkinkan terjadinya kegagalan dalam performa suatu saham.

Sehingga isu bertahannya suatu saham di LQ45 menjadi cukup menarik, khususnya dalam hal psikologi sebagai saham bluechips, yaitu apakah kinerja yang dicapai sebelum masuk ke LQ45 dipertahankan hingga saat saham itu berada di dalam LQ45? Dengan kata lain, apakah seorang pemenang tetap menjaga kemenangannya?

\section{METODE PENELITIAN}

Masuk-keluarnya suatu saham dari kelompok blue-chips dapat mempengaruhi kinerja perusahaan, baik pengaruh positif maupun pengaruh negatif. Pengaruh positifnya dapat berupa perbaikan pada kinerja, sedangkan pengaruh negatifnya adalah se- baliknya. Pengaruh positif ini bisa diakibatkan dorongan perusahaan untuk memenuhi persyaratan untuk bisa masuk ke LQ45 ataupun untuk mempertahankan posisi di LQ45. Pengaruh yang negatif bisa diakibatkan oleh menurunnya semangat menjaga kinerja setelah saham tersebut keluar dari LQ45. Penelitian ini memfokuskan pada periode 2012 hingga 2015 dengan data per semester. Sehingga periode yang dimiliki berjumlah delapan semester per saham. Periode ini dipilih karena pada periode ini, terjadi kenaikan, kestabilan dan penurunan IHSG di Bursa Efek Indonesia sehingga dipandang cukup mewakili beberapa kondisi yang terjadi di pasar Indonesia. Sahamsaham yang dipilih adalah saham-saham yang pernah masuk dan keluar LQ45 pada periode yang dipilih untuk studi ini. Sektor dari saham ini sangat bervariasi, mulai dari sektor perbankan hingga sektor pertambangan. Tabel 1 mendaftarkan semua saham yang menjadi sampel pada penelitian ini.

Tabel 1

Daftar Saham

\begin{tabular}{lll}
\hline \hline No & Kode Saham & \multicolumn{1}{c}{ Nama Saham } \\
\hline 1 & ANTM & Aneka Tambang (Persero) Tbk \\
2 & BBTN & Bank Tabungan Negara (Persero) Tbk \\
3 & BDMN & Bank Danamon Indonesia Tbk \\
4 & BKSL & Sentul City Tbk \\
5 & CTRA & Ciputra Development Tbk \\
6 & INCO & Vale Indonesia Tbk \\
7 & HRUM & Harum Energy Tbk \\
8 & LPPF & Matahari Department Store Tbk \\
9 & MAIN & Malindo Feedmill Tbk \\
10 & MLPL & Multipolar Tbk \\
11 & MPPA & Matahari Putra Prima Tbk \\
12 & SCMA & Surya Citra Media Tbk \\
13 & SILO & PT. Siloam International Hospitals Tbk \\
14 & SRIL & PT. Sri Rejeki Isman Tbk \\
15 & SSIA & Surya Semesta Internusa Tbk \\
16 & SSMS & PT. Sawit Sumbermas Sarana Tbk \\
17 & TAXI & Express Transindo Utama Tbk \\
18 & VIVA & PT. Visi Media Asia Tbk \\
19 & WTON & Wijaya Karya Beton Tbk \\
\hline Sum
\end{tabular}

Sumber: Data Penulis 
Tabel 2 di bawah ini menunjukkan perpindahan saham di LQ45, baik masuk maupun keluar, pada periode 2014-2016. Saham Aneka Tambang (ANTM) merupakan saham yang melakukan perpindahan dua arah, yaitu masuk dan keluar. Sedang- kan saham lainnya hanya melakukan perpindahan satu arah, hanya masuk atau keluar saja.

Perpindahan terjadi setiap 6 bulan sebagaimana didasarkan pada evaluasi Bursa Efek Indonesia (BEI).

Tabel 2

Perpindahan Saham Masuk dan Keluar LQ45 periode 2014-2016

\begin{tabular}{|c|c|c|c|}
\hline No & Periode Waktu Indeks Lq-45 & Masuk & Keluar \\
\hline \multirow[t]{5}{*}{1} & Agustus 2014 - Januari 2015 & ANTM & BKSL \\
\hline & & BBTN & MAIN \\
\hline & & INCO & MLPL \\
\hline & & LPPF & SSIA \\
\hline & & SCMA & VIVA \\
\hline \multirow[t]{3}{*}{2} & Februari 2015 - Juli 2015 & MPPA & BDMN \\
\hline & & SILO & HRUM \\
\hline & & SSMS & TAXI \\
\hline \multirow[t]{2}{*}{3} & Agustus 2015 - Januari 2016 & SRIL & ANTM \\
\hline & & WTON & CTRA \\
\hline
\end{tabular}

Pada penelitian ini, Profit $t_{i t}$ adalah variable profitabilitas untuk saham $i=1, \ldots, N$ yang diobservasi pada periode $t=1, \ldots, T$ dengan mengikuti model regresi panel berikut ini:

$$
\text { Profit }_{i t}=\alpha+x^{\prime}{ }_{i t} \beta+c_{i}+u_{i t}
$$

di mana $x^{\prime}{ }_{i t}$ adalah vektor baris berdimensi $K$ dari variabel independen yang berubah setiap periode, $\alpha$ adalah intersep, $\beta$ adalah vektor kolom dari parameter berdimensi $K$, $c_{i}$ adalah individual-specific effect dan $u_{i t}$ adalah idiosyncratic error term. Variabel kunci pada penelitian ini adalah variabel keluarmasuk (in-out) dan variabel kontrol adalah variabel-variabel pasar dan indikator kinerja keuangan. Variabel in-out merupakan variabel dummy atau binari yang diberikan kode 1 jika saham tersebut berada dalam LQ45 dan 0 jika saham tersebut diluar LQ45.

Selain itu, penelitian ini juga mencoba menginvestigasi apakah variabel pasar dan indikator keuangan saham di masa lampau mempengaruhi status in-out saham tersebut di LQ45. Untuk investigasi ini, penelitian menggunakan teknik regresi logistik dengan spesifikasi sebagai berikut: $p_{i t} \equiv \operatorname{Pr}\left(y_{i t}=1 \mid x_{i t-1}\right)=e^{x_{i t-1}^{\prime} \beta} /(1+$
$\left.\quad e^{x_{i t-1} \beta}\right)$

di mana $x_{i t-1}^{\prime}$ adalah vektor baris berdimensi $K$ dari variabel independen pada periode $t-1$ yaitu indicator kinerja perusahaan di masa lampau, $e$ adalah nilai eksponen, $\beta$ adalah vektor kolom dari parameter berdimensi K. Variabel kunci pada penelitian ini adalah variabel-variabel pasar dan indikator kinerja keuangan. Sedangkan variabel $y_{i t}$ adalah variabel binari status saham di LQ45, dimana masuk $=1$ dan keluar $=0$.

Tabel 3 di bawah ini mendaftarkan summary statistics dari variabel yang digunakan pada penelitian ini sedangkan Table 4 mendaftarkan summary statistics dari variabel yang diukur pada masa lampau ( $t$ 1) atau disebut sebagai variabel lag. Periode yang dipilih untuk merepresentasikan lag adalah 1 periode sebelumnya, dalam hal ini adalah 1 semester sebelumnya. Tabel 3 dan 4 menunjukkan variabel pasar dan indikator keuangan yang digunakan dalam penelitian ini. 
Variabel pasar yang digunakan adalah volume perdagangan (vp), nilai $\log$ dari vp (log_vp), kapitalisasi pasar (kp), nilai log dari kp (log_kp), dan variabel binari masukkeluar (inout). Sedangkan indikator keuangan perusahaan adalah return on asset (roa), net profit margin (npm), debt to asset ratio, equity ratio, long-term debt to equity ratio, gross profit, net profit after tax, liability, asset, long term debt, equity, nilai log dari asset (log_asset) dan nilai log dari liability (log_liability). Selain variabel pasar dan indikator, penelitian ini menggunakan variabel makro yaitu produk domestik bruto (PDB), nilai log dari PDB (log_pdb). Pada prinsipnya, variabel pasar inilah yang menjadi variabel yang dipandang Bursa Efek Indonesia sebagai variabel yang dapat menentukan status saham di LQ45, yaitu volume perdagangan dan kapitalisasi pasar.

Tabel 3

Summary Statistics

\begin{tabular}{lcccc}
\hline \multicolumn{1}{c}{ Variable } & Obs & Mean & Min & Max \\
\hline Stockid & 152 & 10 & 1 & 19 \\
Periode & 76 & 2013.5 & 2012 & 2015 \\
Semester & 152 & 1.5 & 1 & 2 \\
Period & 152 & 4.5 & 1 & 8 \\
timeorder & 152 & 76.5 & 1 & 152 \\
Vp & 138 & $4.95 \mathrm{E}+09$ & 33000 & $4.69 \mathrm{E}+10$ \\
log_vp & 138 & 9.297746 & 4.52 & 10.67 \\
pdb & 152 & 143430.8 & 3343.7 & 459161.8 \\
log_pdb & 152 & 5.008036 & 3.52 & 5.661966 \\
roa & 138 & 0.09 & -0.1148 & 2.8 \\
kp & 138 & $1.47 \mathrm{E}+13$ & $2.25 \mathrm{E}+11$ & $5.69 \mathrm{E}+13$ \\
log_kp & 138 & 12.99 & 11.35 & 13.76 \\
inout & 152 & 0.12 & 0 & 1 \\
npm & 97 & 48.04 & -92.28 & 932.81 \\
debt_asset ratio & 97 & 78.064 & 18.74 & 2058.58 \\
longtermdebt_equity ratio & 96 & 89.59 & -796.46 & 704.07 \\
grossprofit & 97 & 1284836 & 43867 & 6866503 \\
netprofitaftertax & 97 & 465647.7 & -1246531 & 2108188 \\
liability & 97 & $1.35 \mathrm{E}+07$ & 455204 & $1.58 \mathrm{E}+08$ \\
asset & 97 & $1.72 \mathrm{E}+07$ & 239916 & $1.72 \mathrm{E}+08$ \\
longtermdebt & 96 & 7934968 & 18754 & $9.72 \mathrm{E}+07$ \\
equity & 97 & 4169650 & -2544950 & $1.39 \mathrm{E}+07$ \\
log_asset & 97 & 15.63 & 12.39 & 18.96 \\
log_liability & 97 & 15.00 & 13.03 & 18.88 \\
\hline
\end{tabular}

Sumber: Data Penulis

Di lain pihak, penelitian ini juga memiliki variabel-variabel masa lampau, yaitu variabel yang diukur pada masa lampau $(t-$
1). Tabel 4 menghadirkan variabel lag dari inout (inout_lag), variabel lag dari net profit margin (npm_lag), variable lag dari debt to 
asset ratio (dar_lag), variabel lag dari long term debt to equity ratio (1tde_ratio_lag), variabel lag dari gross profit (grossprofit_lag), variabel lag dari net profit (netprofit_lag), variabel lag dari liability (liability_lag), variabel lag dari asset (asset_lag), variabel lag dari long term debt (long-termdebt_lag) dan variabel lag dari equity (equity_lag).

Tabel 4

Summary Statistics

\begin{tabular}{lcccc}
\hline \multicolumn{1}{c}{ Variable } & Obs & Mean & Min & Max \\
\hline stockid & 152 & 10 & 1 & 19 \\
inout_lag & 133 & 0.12 & 0 & 1 \\
npm_lag & 84 & 52.97 & -80.54 & 932.81 \\
dar_lag & 84 & 81.22 & 18.74 & 2058.58 \\
ltde_ratio_lag & 83 & 88.07 & -796.46 & 704.07 \\
grossprofit_lag & 84 & 1174229 & 43867 & 5639018 \\
netprofit_lag & 84 & 467841.4 & -405811 & 2108188 \\
liability_lag & 84 & $1.32 \mathrm{E}+07$ & 463680 & $1.43 \mathrm{E}+08$ \\
asset_lag & 84 & $1.68 \mathrm{E}+07$ & 239916 & $1.56 \mathrm{E}+08$ \\
longtermdebt_lag & 83 & 7771513 & 18754 & $8.98 \mathrm{E}+07$ \\
equity_lag & 84 & 4037684 & -2544950 & $1.28 \mathrm{E}+07$ \\
\hline
\end{tabular}

Sumber: Data Penulis

\section{ANALISIS DAN PEMBAHASAN}

Analisa data pada penelitian ini dimulai dengan mereplikasi penelitian yang dilakukan oleh Prasetya dan Tasik (2017) dengan menggunakan model regresi logistik. Hasil replikasi ditunjukkan pada Tabel 5 yang menunjukkan bahwa hanya volume perdagangan yang mempengaruhi status inout dari saham di LQ45. Sebagaimana yang ditemukan oleh Prasteya dan Tasik, kapitalisasi pasar, return on asset (ROA) dan produk domestik bruto (PDB) tidak memiliki pengaruh yang signifikan pada periode yang sama dengan periode inout.

Hasil pada Tabel 5 menjadi lampu hijau untuk melakukan penelitian ini, khususnya dalam mengukur pengaruh variable inout terhadap indikator kinerja perusahaan. Indikator yang digunakan pada penelitian ini adalah indikator profitabilitas yang diproxi oleh net profit margin (NPM). Pemilihan NPM sebagai proxi didasarkan pada kebutuhan untuk melihat selisih dari laba yang didapatkan perusahaan dan NPM adalah salah satu indikator yang dapat merepresentasikannya.
Tabel 5

Model In-Out dengan Menggunakan Teknik Regresi Logistik

\begin{tabular}{|c|c|c|}
\hline VARIABLES & $\begin{array}{c}\text { (1) } \\
\text { inout }\end{array}$ & $\begin{array}{c}(2) \\
\text { lnsig2u }\end{array}$ \\
\hline $\mathrm{Kp}$ & $\begin{array}{c}1.41 \mathrm{e}-14 \\
(1.91 \mathrm{e}-14)\end{array}$ & \\
\hline $\mathrm{Vp}$ & $\begin{array}{l}5.30 \mathrm{e}-11^{*} \\
(2.87 \mathrm{e}-11)\end{array}$ & \\
\hline Roa & $\begin{array}{l}-0.30 \\
(1.25)\end{array}$ & \\
\hline $\mathrm{Pdb}$ & $\begin{array}{c}1.47 \mathrm{e}-06 \\
(2.53 \mathrm{e}-06)\end{array}$ & \\
\hline Constant & $\begin{array}{c}-2.61^{* * *} \\
(0.64)\end{array}$ & $\begin{array}{l}-14.05 \\
(42.55)\end{array}$ \\
\hline Observations & 138 & 138 \\
\hline Number of stockid & 19 & 19 \\
\hline \multicolumn{3}{|c|}{$\begin{array}{l}\text { Standard errors in parentheses } \\
* * * p<0.01,{ }^{* *} p<0.05,{ }^{*} p<0.1 \\
\text { Sumber: Perhitungan Penulis }\end{array}$} \\
\hline \multicolumn{3}{|c|}{$\begin{array}{l}\text { Gambar } 1 \text { menunjukkan perkembangan } \\
\text { masuk-keluar saham di LQ45. Berdasarkan } \\
\text { gambar ini, hampir semua saham hanya } \\
\text { memiliki satu kali kesempatan masuk pada } \\
\text { indeks LQ45. }\end{array}$} \\
\hline
\end{tabular}



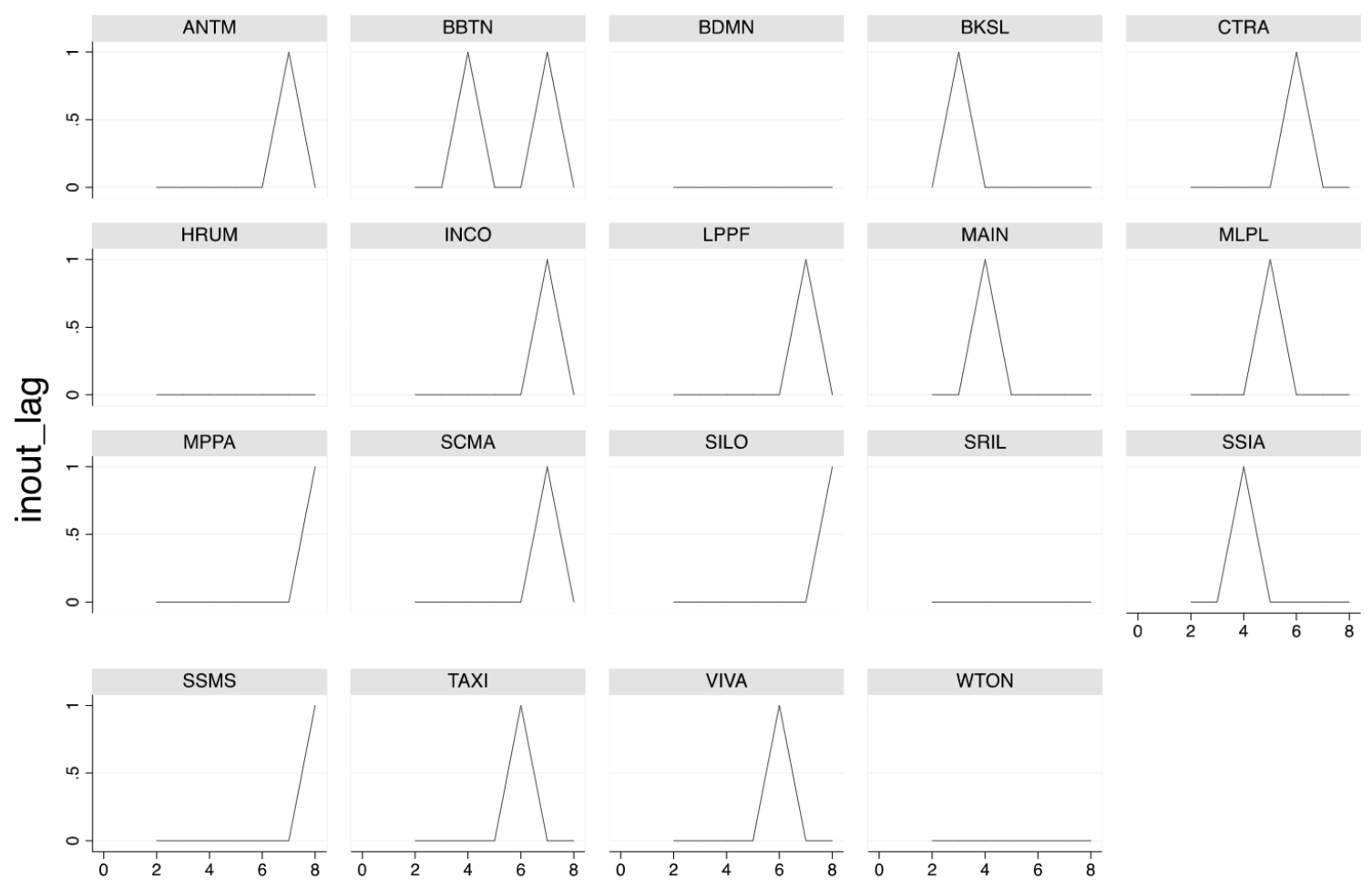

Graphs by SAHAM
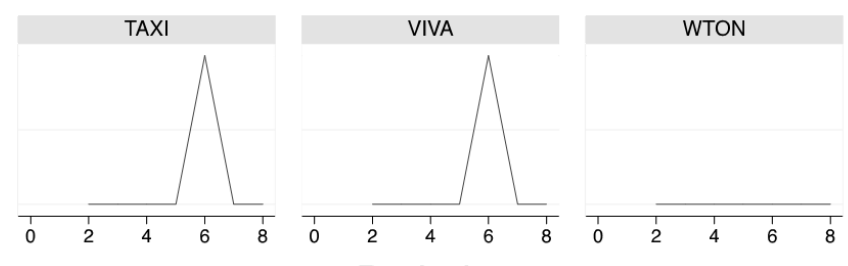

Period

Sumber: Data Penulis

\section{Gambar 1 \\ Perkembangan Masuk-Keluar Saham di LQ45 di Periode Studi}

Hanya satu saham yang memiliki dua kali kesempatan masuk ke LQ45, yaitu saham BBTN. Hal ini ditunjukkan oleh grafik yang memiliki dua puncak. Periode masuk dari saham-saham yang ada pada sampel ini bervariasi, banyak saham yang masuk di tengah periode studi, beberapa masuk mendekati akhir periode, dan ada yang masuk pada akhir periode seperti saham MPPA dan SSMS. Tabel 6 menunjukkan spesifikasi untuk model NPM dengan menggunakan teknik regresi data panel yaitu dengan mengontrol variable inout dan debt to asset ratio (spesifikasi (1)), sedangkan spesifikasi (2) mengontrol variable tambahan net profit after tax, dan spesifikasi (3) mengontrol variable tambahan liability. Hasil pada Tabel 6 menyarankan bahwa variable inout pada periode sebelumnya memiliki pengaruh terhadap pembentukan NPM, yaitu, sahamsaham yang berada pada LQ45 memiliki
NPM dengan 19,50 poin (spesifikasi (3)) hingga 24,44 poin (spesifikasi (1)) lebih tinggi dari saham-saham yang berada di luar LQ45.

Spesifikasi-spesifikasi pada model 5 menyimpulkan bahwa variable inout pada 1 periode sebelumnya memiliki pengaruh terhadap NPM. Variabel debt to asset ratio dan net profit after tax juga memiliki pengaruh di semua spesifikasi. Liability tidak memiliki pengaruh terhadap NPM. Sebagaimana pada Table 6, Tabel 7 juga menunjukkan bahwa variabel inout secara konsisten mempengaruhi perubahan NPM dengan mengontrol beberapa indicator keuangan lainnya, dalam hal ini, yaitu gross profit (spesifikasi (1)), long term debt to equity ratio (spesifikasi (2)), dan ROA (spesifikasi (3)). Variabel lainnya yang juga memiliki pengaruh signifikan adalah debt to asset ratio, net profit after tax, dan gross profit. Sedangkan ROA tidak memiliki pengaruh signifikan. 
84 Ekuitas: Jurnal Ekonomi dan Keuangan - Volume 3, Nomor 1, Maret 2019: 72 - 94

Tabel 6

Model NPM dengan Indikator Keuangan (bagian 1)

\begin{tabular}{|c|c|c|c|}
\hline VARIABLES & $\begin{array}{c}(1) \\
\text { npm }\end{array}$ & $\begin{array}{c}(2) \\
\text { npm }\end{array}$ & $\begin{array}{c}(3) \\
\text { npm }\end{array}$ \\
\hline inout_lag & $\begin{array}{l}24.44^{*} \\
(12.77)\end{array}$ & $\begin{array}{c}18.26 \\
(11.42)\end{array}$ & $\begin{array}{l}19.50^{*} \\
(11.29)\end{array}$ \\
\hline debt_asset_ratio & $\begin{array}{l}-0.46^{* *} \\
(0.21)\end{array}$ & $\begin{array}{c}-0.65^{* * *} \\
(0.18)\end{array}$ & $\begin{array}{c}-0.56^{* * *} \\
(0.19)\end{array}$ \\
\hline netprofit_aftertax & & $\begin{array}{c}0.00004^{* * *} \\
(7.61 \mathrm{e}-06)\end{array}$ & $\begin{array}{l}0.00004^{* * *} \\
(7.85 \mathrm{e}-06)\end{array}$ \\
\hline liability & & & $\begin{array}{l}-0.00 \\
(0.00)\end{array}$ \\
\hline Constant & $\begin{array}{c}62.41^{* * *} \\
(14.54)\end{array}$ & $\begin{array}{c}55.13^{* * *} \\
(11.69)\end{array}$ & $\begin{array}{c}51.78^{* * *} \\
(12.12)\end{array}$ \\
\hline Observations & 88 & 88 & 88 \\
\hline Number of stockid & 13 & 13 & 13 \\
\hline
\end{tabular}

Tabel 7

Model NPM dengan Indikator Keuangan (bagian 2)

\begin{tabular}{|c|c|c|c|}
\hline VARIABLES & $\begin{array}{c}(1) \\
\text { npm }\end{array}$ & $\begin{array}{c}\text { (2) } \\
\text { npm }\end{array}$ & $\begin{array}{c}\text { (3) } \\
\text { npm }\end{array}$ \\
\hline inout_lag & $17.78^{*}$ & $24.35^{*}$ & $24.77^{*}$ \\
\hline & (10.53) & $(12.84)$ & $(13.25)$ \\
\hline debt_asset_ratio & $\begin{array}{l}-0.30 \\
(0.19)\end{array}$ & $\begin{array}{l}-0.46^{* *} \\
(0.22)\end{array}$ & $\begin{array}{c}-0.51^{* *} \\
(0.22)\end{array}$ \\
\hline netprofit_aftertax & $\begin{array}{c}0.00006^{* * *} \\
(9.24 \mathrm{e}-06)\end{array}$ & & \\
\hline grossprofit & $\begin{array}{c}-0.00002^{* * *} \\
(4.61 \mathrm{e}-06)\end{array}$ & & \\
\hline longtermdebt_equity_ratio & & $\begin{array}{l}-0.00 \\
(0.03)\end{array}$ & \\
\hline roa & & & $\begin{array}{c}13.98 \\
(16.31)\end{array}$ \\
\hline Constant & $\begin{array}{c}47.95^{* * *} \\
(11.39)\end{array}$ & $\begin{array}{c}62.49^{* * *} \\
(14.99)\end{array}$ & $\begin{array}{c}62.78^{* * *} \\
(14.85)\end{array}$ \\
\hline Observations & 88 & 88 & 83 \\
\hline Number of stockid & 13 & 13 & 13 \\
\hline
\end{tabular}

Berbeda dengan Tabel 6 dan 7 yang hanya mengontrol indikator keuangan, tabel 8 menunjukkan spesifikasi model regresi data panel yang juga memperhitungkan variabel pasar, yaitu, volume perdagangan (VP) dan kapitalisasi pasar (KP). Tujuan memasukkan variabel pasar pada model adalah untuk melihat lebih akurat pengaruh 
inout dengan jenis variabel terkait yang lebih banyak. Hasil pada Tabel 8 menunjukkan bahwa variabel inout tetap konsisten mempengaruhi NPM sedangkan variabel pasar VP dan KP juga memiliki pengaruh yang signifikan terhadap perubahan NPM dari ke19 saham terdaftar LQ45 yang ada. Namun, variable log dari VP tidak memiliki pengaruh meski VP itu sendiri memiliki pengaruh terhadap perubahan NPM.

Tabel 8

Model NPM dengan Indikator Keuangan dan Variabel Pasar (bagian 1)

\begin{tabular}{cccc}
\hline Variables & $\begin{array}{c}\mathbf{( 1 )} \\
\mathbf{n p m}\end{array}$ & $\begin{array}{c}\mathbf{( 2 )} \\
\mathbf{n p m}\end{array}$ & $\begin{array}{c}\mathbf{( 3 )} \\
\mathbf{n p m}\end{array}$ \\
\hline inout_lag & $23.52^{*}$ & $25.03^{*}$ & $22.73^{*}$ \\
& $(13.27)$ & $(12.84)$ & $(13.19)$ \\
debt_asset_ratio & $-0.44^{*}$ & $-0.45^{* *}$ & $-0.48^{* *}$ \\
& $(0.24)$ & $(0.22)$ & $(0.21)$ \\
log_vp & 6.82 & & \\
& $(8.44)$ & & \\
Vp & & $1.87 \mathrm{e}-09^{* *}$ & \\
& & $(8.61 \mathrm{e}-10)$ & \\
Kp & & & $8.58 \mathrm{e}-13^{* *}$ \\
& & & $(4.36 \mathrm{e}-13)$ \\
Constant & -2.85 & $51.93^{* * *}$ & $51.39^{* * *}$ \\
& $(85.04)$ & $(15.95)$ & $(15.16)$ \\
Observations & 83 & 83 & 83 \\
Number of stockid & 13 & 13 & 13 \\
\hline
\end{tabular}

Standard errors in parentheses

${ }^{* * *} \mathrm{p}<0.01,{ }^{* *} \mathrm{p}<0.05,{ }^{*} \mathrm{p}<0.1$

Sumber: Perhitungan Penulis

Tabel 9

Model NPM dengan Indikator Keuangan dan Variabel Pasar (bagian 2)

\begin{tabular}{|c|c|c|c|c|}
\hline VARIABLES & $\begin{array}{c}(1) \\
\text { npm }\end{array}$ & $\begin{array}{c}(2) \\
\text { npm }\end{array}$ & $\begin{array}{c}(3) \\
\text { npm }\end{array}$ & $\begin{array}{c}(4) \\
\text { npm }\end{array}$ \\
\hline \multirow{2}{*}{ inout_lag } & $22.77^{*}$ & 20.36 & $22.86^{*}$ & 19.00 \\
\hline & (12.66) & (13.63) & (12.76) & (11.66) \\
\hline debt_asset_ratio & $-0.39 *$ & $-0.39 * *$ & $-0.38^{*}$ & $-0.64^{* * *}$ \\
\hline & $(0.20)$ & $(0.19)$ & $(0.20)$ & $(0.19)$ \\
\hline $\mathrm{Kp}$ & $\begin{array}{c}1.20 \mathrm{e}-12^{* * *} \\
(4.37 \mathrm{e}-13)\end{array}$ & $\begin{array}{c}1.00 \mathrm{e}-12^{* * *} \\
(3.84 \mathrm{e}-13)\end{array}$ & $\begin{array}{c}1.20 \mathrm{e}-12^{* * *} \\
(4.39 \mathrm{e}-13)\end{array}$ & $\begin{array}{c}0.00 \\
(0.00)\end{array}$ \\
\hline $\mathrm{Vp}$ & $\begin{array}{c}2.27 \mathrm{e}-09^{* * *} \\
(8.13 \mathrm{e}-10)\end{array}$ & & $\begin{array}{c}2.31 \mathrm{e}-09^{* * *} \\
(8.79 \mathrm{e}-10)\end{array}$ & $\begin{array}{c}0.00 \\
(0.00)\end{array}$ \\
\hline log_vp & & $\begin{array}{l}10.70 \\
(7.82)\end{array}$ & & \\
\hline Equity & & & $\begin{array}{l}-0.00 \\
(0.00)\end{array}$ & \\
\hline netprofit_aftertax & & & & $\begin{array}{l}0.00004^{* * *} \\
(8.78 \mathrm{e}-06)\end{array}$ \\
\hline Constant & $\begin{array}{l}29.29^{*} \\
(16.57)\end{array}$ & $\begin{array}{c}-55.72 \\
(79.93)\end{array}$ & $\begin{array}{l}29.81^{*} \\
(17.00)\end{array}$ & $\begin{array}{c}44.19^{* * *} \\
(15.06)\end{array}$ \\
\hline
\end{tabular}




\begin{tabular}{lllll}
\multicolumn{1}{c}{ Observations } & 83 & 83 & 83 & 83 \\
\multicolumn{1}{|c}{ Number of stockid } & 13 & 13 & 13 & 13 \\
\hline Standard errors in parentheses & & & & \\
$* * * \mathbf{p}<\mathbf{0 . 0 1}{ }^{* *} \mathbf{p}<\mathbf{0 . 0 5}{ }^{*} \mathbf{p}<\mathbf{0 . 1}$ & & & & \\
Sumber: Perhitungan Penulis & &
\end{tabular}

Tabel 9 juga menunjukkan konsistensi pengaruh inout terhadap NPM kecuali pada spesifikasi (2) dan (4), yaitu di saat model mongontrol log-vp (spesifikasi (2)) dan net proifit after tax bersama dengan volume perdagangan dan kapitalisasi pasar (spesifikasi (4)).

Cukup mengejutkan bahwa semua variable pasar (KP dan VP) memiliki pengaruh signifikan terhadap NPM (spesifikasi (1) dan (3)). Pada model ini pengaruh variable inout adalah NPM dari sahamsaham yang berada di LQ45 akan berada pada 22.77 poin hingga 22.86 poin lebih tinggi dari saham-saham yang berada di luar LQ45. Pengaruh kapitalisasi pasar pada spesifikasi (1) dan (3) relatif sama sedangkan volume perdagangan pada spesifikasi (3) memiliki pengaruh yang lebih besar dari spesifikasi (1). Sebagaimana dijelaskan sebelumnya, kapitalisasi pasar dan volume perdagangan merupakan dua variabel yang dianggap mempengaruhi keluar-masuk saham di LQ 45 (inout) pada periode yang sama menurut Bursa Efek Indonesia (BEI).

Satu hal yang menarik pada hasil di Tabel 9 adalah saat equity dikontrol (spesifikasi (3)), efek dari volume perdagangan meningkat dibanding saat equity tidak dikontrol (spesifikasi (1)). Net profit after tax juga memiliki pengaruh signifikan terhadap perubahan NPM (spesifikasi (4)). Sebagaimana di Tabel 8, hasil yang ditunjukkan di Tabel 9 juga memperlihatkan kalau volume perdagangan dalam bentuk $\log$ tidak memiliki pengaruh, berbeda dengan nilai volume yang sebenarnya.

Selanjutnya, Tabel 10 memperlihatkan hasil regresi panel dengan menggunakan indikator keuangan yang lain, yaitu log asset, log liability. Juga, tabel ini memperlihatkan hasil regresi dengan mengontrol variabel pasar dalam bentuk $\log$, yaitu $\log k p$ dan $\log$ vp. Sekali lagi, variabel inout seara konsisten mempengaruhi NPM di spesifikasi (1) sampai (3). Di saat model menggunakan nilai log dari volume perdagangan dan kapitalisasi pasar, efek dari inout menjadi tidak signifikan. Besaran dari efek inout berkisar pada 21,60 sampai 23,73 di mana itu berarti bahwa saham yang berada pada LQ45 memiliki NPM 21,60 sampai 23,73 poin lebih besar dari saham yang berada di luar LQ45.

Yang menarik di sini adalah, pengaruh signifikan dari kapitalisasi pasar baik dalam nilai sebenarnya (spesifikasi (1)) maupun dalam nilai log (spesifikasi (3)) tetap konsisten. Sedangkan volume perdagangan hanya memberi pengaruh signifikan pada nilai sebenarnya dan tidak pada nilai log. Debt to asset ratio memiliki pengaruh signifikan di semua spesifikasi kecuali pada spesifikasi (2). Pengaruh dari debt to asset ratio memiliki pengaruh signifikan dengan kisaran $-0,35$ sampai $-0,40$ yang artinya penambahan 1 persen pada debt to asset ratio, NPM akan berkurang dengan kisaran -0,35 sampai 0,40 .

Di saat variabel makro diperhitungkan baik dalam bentuk nilai sebenarnya maupun nilai $\log$, variabel inout tetap konsisten mempengaruhi NPM secara signifikan. Variabel yang diambil pada studi ini adalah Produk Domestik Bruto (PDB).

Tabel 11 menunjukkan hasil regresi data panel dengan mengontrol variabel makro. Spesifikasi (1) menggunakan nilai PDB dalam bentuk log sedangkan spesifikasi (2) menggunakan nilai PDB yang sebenarnya. Hasil dari regresi ini menyarankan bahwa NPM tidak dipengaruhi oleh keberadaan PDB di Indonesia tapi jauh lebih dipengaruhi oleh faktor pasar dan faktor internal perusahaan, yaitu indikator keuangan.

Besaran pengaruh inout berkisar pada 23,18 sampai 24,59 yang berarti bahwa 
saham-saham yang berada di LQ45 memiliki NPM 23,18 sampai 24,59 poin lebih tinggi dari saham-saham yang tidak berada di
LQ45. Debt to asset ratio juga secara konsisten mempengaruhi NPM di saat variabel makro dikontrol.

Tabel 10

Model NPM dengan Indikator Keuangan dan Variabel Pasar (bagian 3)

\begin{tabular}{|c|c|c|c|c|}
\hline VARIABLES & $\begin{array}{c}\text { (1) } \\
\text { npm }\end{array}$ & $\begin{array}{c}\text { (2) } \\
\text { npm }\end{array}$ & $\begin{array}{c}\text { (3) } \\
\text { npm }\end{array}$ & $\begin{array}{c}\text { (4) } \\
\text { npm }\end{array}$ \\
\hline inout_lag & $\begin{array}{l}23.45^{*} \\
(12.67)\end{array}$ & $\begin{array}{l}23.73^{*} \\
(12.57)\end{array}$ & $\begin{array}{l}21.60^{*} \\
(12.23)\end{array}$ & $\begin{array}{c}20.18 \\
(12.97)\end{array}$ \\
\hline debt_asset_ratio & $\begin{array}{l}-0.35^{*} \\
(0.21)\end{array}$ & $\begin{array}{l}-0.26 \\
(0.25)\end{array}$ & $\begin{array}{l}-0.40^{*} \\
(0.21)\end{array}$ & $\begin{array}{l}-0.39^{*} \\
(0.22)\end{array}$ \\
\hline $\mathrm{Kp}$ & $\begin{array}{c}1.19 \mathrm{e}-12^{* * *} \\
(4.52 \mathrm{e}-13)\end{array}$ & $\begin{array}{l}1.16 e-12^{* *} \\
(4.63 e-13)\end{array}$ & & \\
\hline $\mathrm{Vp}$ & $\begin{array}{c}2.43 \mathrm{e}-09^{* * *} \\
(8.53 \mathrm{e}-10)\end{array}$ & $\begin{array}{c}2.50 \mathrm{e}-09^{* * *} \\
(8.57 \mathrm{e}-10)\end{array}$ & $\begin{array}{c}2.48 \mathrm{e}-09^{* * *} \\
(8.38 \mathrm{e}-10)\end{array}$ & \\
\hline log_asset & $\begin{array}{l}-3.53 \\
(5.85)\end{array}$ & & & \\
\hline log_liability & & $\begin{array}{l}-5.36 \\
(5.72)\end{array}$ & & \\
\hline $\log _{-} k p$ & & & $\begin{array}{c}45.52^{* * *} \\
(14.45)\end{array}$ & $\begin{array}{l}35.99 * * \\
(14.15)\end{array}$ \\
\hline $\log _{-} v p$ & & & & $\begin{array}{c}9.52 \\
(8.17)\end{array}$ \\
\hline Constant & $\begin{array}{c}82.10 \\
(89.52)\end{array}$ & $\begin{array}{l}101.83 \\
(79.88)\end{array}$ & $\begin{array}{c}-543.63^{* * *} \\
(189.67)\end{array}$ & $\begin{array}{c}-496.65^{* *} \\
(211.07)\end{array}$ \\
\hline Observations & 83 & 83 & 83 & 83 \\
\hline Number of stockid & 13 & 13 & 13 & 13 \\
\hline
\end{tabular}

Standard errors in parentheses

*** $p<0.01,{ }^{* *} p<0.05,{ }^{*} p<0.1$

Sumber: Perhitungan Penulis

Tabel 11

Model NPM dengan Indikator Keuangan, Variabel Pasar dan Variabel Makro

\begin{tabular}{lcc}
\hline Variables & $\begin{array}{c}\mathbf{( 1 )} \\
\mathbf{n p m}\end{array}$ & $\begin{array}{c}\mathbf{( 2 )} \\
\mathbf{n p m}\end{array}$ \\
\hline inout_lag & $24.59^{*}$ & $23.18^{*}$ \\
& $(12.68)$ & $(12.58)$ \\
debt_asset_ratio & $-0.46^{* *}$ & $-0.38^{*}$ \\
& $(0.23)$ & $(0.22)$ \\
kp & & $1.20 \mathrm{e}-12^{* *}$ \\
& & $(4.79 \mathrm{e}-13)$ \\
vp & & $2.39 \mathrm{e}-09^{* * *}$ \\
& & $(8.62 \mathrm{e}-10)$ \\
pdb & & 0.00 \\
& & $(0.00)$ \\
log_pdb & 1.10 &
\end{tabular}

(16.37)

$\begin{array}{lll}\text { Constant } & 56.89 & 27.93\end{array}$

(82.74) (21.55)

Observations $\quad 88 \quad 83$

Number of stockid $13 \quad 13$

Standard errors in parentheses

${ }^{* * *} \mathrm{p}<0.01,{ }^{* *} \mathrm{p}<0.05,{ }^{*} \mathrm{p}<0.1$

Sumber: Perhitungan Penulis

Dari semua hasil regresi yang ada, yaitu berdasarkan Tabel 9 spesifikasi (1), Tabel 10 spesifikasi (1) dan Tabel 11 spesifikasi (2), dapat dilihat bahwa spesifikasi-spesifikasi inilah yang memiliki jumlah variabel terbanyak yang memberi pengaruh signifikan terhadap NPM. Pada ketiga spesifikasi ini, variabel inout periode sebelumnya, kapitali- 
sasi pasar, volume perdagangan dan debt to asset ratio selalu memiliki pengaruh yang signifikan terhadap NPM. Pada ketiga spe sifikasi ini, pengaruh inout periode sebelumya berkisar dari 22,77 (Tabel 9, spesifikasi (1)) sampai 23,45 (Tabel 10, spesifikasi (1)). Pengaruh kapitalisasi pasar berkisar dari 1,19e12 (Tabel 10 spesifikasi (1)) sampai 1,20e-12 (Tabel 9 spesifikasi (1) dan Tabel 11 spesifikasi (20)). Pengaruh volume perdagangan berkisar pada 2,27e-09 (Tabel 9 spesifikasi (1)) sampai 2.43e-09 (Tabel 10 spesifikasi (1)). Sedangkan pengaruh debt to asset ratio berkisar dari -0,35 (Table 10 spesifikasi (1)) sampai -0,39 (Tabel 9 spesifikasi (1)).

Untuk menguji lebih jauh robustness dari hasil yang didapatkan pada Tabel 9 spesifikasi (1), Tabel 10 spesifikasi (1) dan Tabel 11 spesifikasi (2), studi ini melakukan investigasi lebih lanjut dengan melakukan regresi panel data dengan menggunakan pendekatan fixed effect dan random effect.

Tabel 12 menghadirkan hasil regresi data panel dengan pendekatan fixed effect.
Penggunaan pendekatan fixed effect ini untuk mengontrol efek dari variabel yang tidak berubah sepanjang waktu. Hal ini bertujuan untuk mendapatkan efek yang sebenarnya dari variabel-variabel yang dikontrol. Sebagai contoh, variabel yang tidak berubah sepanjang waktu adalah budaya, etos kerja, sistem manajemen, birorkrasi pengambilan keputusan perusahaan dalam hal kebijakan investasi, jual-beli saham, dan sebagainya. Pengontrolan pada variabel-variabel ini dapat menyaring informasi yang masuk khususnya hal-hal yang mempengaruhi NPM. Dapat dilihat dengan jelas pada Tabel 12, pengaruh dari inout pada periode sebelumnya terjadi peningkatan. Sebelumnya, pengaruh inout periode sebelumhya berkisar dari 22,77 (Tabel 9, spesifikasi (1)) sampai 23,45 (Tabel 10, spesifikasi (1)). Hasil yang ditunjukkan pada Tabel 12, menunjukkan pengaruhnya berkisar 25,36 sampai 26,87. Artinya telah terjadi peningkatan pengaruh dari inout terhadap NPM berkisar 11 persen.

Tabel 11

Model NPM dengan Pendekatan Fixed Effect

\begin{tabular}{|c|c|c|c|}
\hline Variables & $\begin{array}{c}\text { (1) } \\
\text { npm }\end{array}$ & $\begin{array}{c}(2) \\
\text { npm }\end{array}$ & $\begin{array}{c}(3) \\
\text { npm }\end{array}$ \\
\hline \multirow[t]{2}{*}{ inout_lag } & $25.36^{*}$ & $26.87^{* *}$ & $26.21^{* *}$ \\
\hline & (12.89) & (12.57) & (12.11) \\
\hline \multirow[t]{2}{*}{ debt_asset_ratio } & -0.48 & -0.62 & -0.21 \\
\hline & $(0.38)$ & $(0.38)$ & $(0.37)$ \\
\hline \multirow[t]{2}{*}{$\mathrm{kp}$} & $8.69 \mathrm{e}-13$ & $9.90 \mathrm{e}-13$ & $1.51 \mathrm{e}-12^{*}$ \\
\hline & (9.35e-13) & $(9.13 e-13)$ & $(9.03 e-13)$ \\
\hline \multirow[t]{2}{*}{ vp } & $3.24 \mathrm{e}-09^{* * *}$ & $3.05 \mathrm{e}-09^{* *}$ & $3.02 \mathrm{e}-09^{* * *}$ \\
\hline & $(1.20 \mathrm{e}-09)$ & $(1.17 \mathrm{e}-09)$ & $(1.13 e-09)$ \\
\hline log_asset & & $\begin{array}{c}-50.69^{* *} \\
(23.71)\end{array}$ & \\
\hline $\mathrm{pdb}$ & & & $\begin{array}{c}-0.001^{* * *} \\
(0.0004)\end{array}$ \\
\hline Constant & $\begin{array}{c}34.04 \\
(30.80)\end{array}$ & $\begin{array}{l}838.58^{* *} \\
(377.51)\end{array}$ & $\begin{array}{c}178.54^{* * *} \\
(54.65)\end{array}$ \\
\hline Observations & 83 & 83 & 83 \\
\hline R-squared & 0.19 & 0.24 & 0.29 \\
\hline Number of stockid & 13 & 13 & 13 \\
\hline
\end{tabular}


Satu hal yang menarik pada pendekatan fixed effect ini adalah kapitalisasi pasar tidak konsisten mempengaruhi NPM di ketiga spesifikasi pada Tabel 12, sedangkan volume perdagangan memiliki pengaruh yang signifikan dan konsisten di ketiga spesifikasi. Selain itu, dapat diamati bahwa pada variabel debt to asset ratio yang akhirnya tidak memiliki pengaruh. Sebaliknya, pada spesifikasi (3), PDB telah memiliki pengaruh signifikan terhadap NPM dan pengaruhnya negatif. Hal yag sama juga dapat diamati pada variabel log_asset (spesifikasi (2)) yang saat ini sudah memiliki pengaruh yang signifikan terhadap NPM.

Untuk tes selanjutnya, penelitian ini menggunakan pendekatan random effect. Hasil dari pendekatan ini dipresentasikan pada Tabel 13. Pada Tabel 13 bahwa, ratarata besaran pengaruh dari inout dengan menggunakan pendekatan random effect lebih kecil dibanding dengan besaran pengaruh dengan menggunakan pendekatan fixed effect. Penurunan besaran pengaruh pada pendekatan random effect diduga sebagai akibat dari adanya term yang tidak dapat dikontrol dan term tersebut masuk di dalam error term. Sedangkan pada pendekatan fixed effect, term yang bersifat konstan sepanjang waktu dikontrol sehingga dapat dilihat besaran pengaruh inout yang lebih tepat, yang dalam hal ini adalah lebih besar dibanding dengan besarannya dengan menggunakan pendekatan random effect.

Untuk melakukan pemilihan apakah pendekatan fixed effect yang dipilih atau random effect, penelitian ini dilanjutkan dengan melakukan uji Hausman (Hausman, 1978), yaitu dengan mendapatkan statistic Hausman yang terdistribusi secara $\chi 2$ dan dihitung dengan

$H=(\beta c-\beta e)^{\prime}(V c-V e)-1(\beta c-\beta e)$

Tabel 13

Model NPM dengan Pendekatan Random Effect

\begin{tabular}{|c|c|c|c|}
\hline Variables & $\begin{array}{c}(1) \\
\text { npm }\end{array}$ & $\begin{array}{c}(2) \\
\text { npm }\end{array}$ & $\begin{array}{c}(3) \\
\text { npm }\end{array}$ \\
\hline inout_lag & $\begin{array}{l}22.77^{*} \\
(12.66)\end{array}$ & $\begin{array}{l}23.45^{*} \\
(12.67)\end{array}$ & $\begin{array}{l}23.18^{*} \\
(12.58)\end{array}$ \\
\hline debt_asset_ratio & $\begin{array}{l}-0.39^{*} \\
(0.20)\end{array}$ & $\begin{array}{l}-0.35^{*} \\
(0.21)\end{array}$ & $\begin{array}{l}-0.38^{*} \\
(0.22)\end{array}$ \\
\hline $\mathrm{Kp}$ & $\begin{array}{c}1.20 \mathrm{e}-12^{* * *} \\
(4.37 \mathrm{e}-13)\end{array}$ & $\begin{array}{c}1.19 \mathrm{e}-12^{* * *} \\
(4.52 \mathrm{e}-13)\end{array}$ & $\begin{array}{l}1.20 \mathrm{e}-12^{* *} \\
(4.79 \mathrm{e}-13)\end{array}$ \\
\hline $\mathrm{Vp}$ & $\begin{array}{c}2.27 \mathrm{e}-09^{* * *} \\
(8.13 \mathrm{e}-10)\end{array}$ & $\begin{array}{c}2.43 \mathrm{e}-09^{* * *} \\
(8.53 \mathrm{e}-10)\end{array}$ & $\begin{array}{l}2.39-09^{* * *} \\
(8.62 \mathrm{e}-10)\end{array}$ \\
\hline log_asset & & $\begin{array}{l}-3.53 \\
(5.85)\end{array}$ & \\
\hline $\mathrm{Pdb}$ & & & $\begin{array}{l}4.14 \mathrm{e}-06 \\
(0.00007)\end{array}$ \\
\hline Constant & $\begin{array}{l}29.29^{*} \\
(16.57)\end{array}$ & $\begin{array}{c}82.10 \\
(89.52)\end{array}$ & $\begin{array}{c}27.93 \\
(21.55)\end{array}$ \\
\hline Observations & 83 & 83 & 83 \\
\hline Number of stockid & 13 & 13 & 13 \\
\hline
\end{tabular}

di mana $\beta c$ adalah vektor koefisien dari estimator yang konsisten, $\beta e$ adalah vektor koefisien dari estimator efisien, $V c$ adalah matrix kovarians dari estimator konsisten, 
dan Ve adalah matrix kovarians dari estimator efisien.

Penelitian ini akan melakukan Hausman test untuk ketiga spesifikasi pada Tabel 12 dan 13. Tabel 14 memperlihatkan hasil dari Hausman test dari Tabel 10 spesifikasi (1) dan tabel 12 spesifikasi (1).

Hausman test didasarkan pada tes spesifikasi Hausman (1978) yang membandingkan estimator satu yang dianggap konsisten dengan estimator yang lain yang dianggap efisien dengan hipotesa nol yaitu estimator yang lain merupakan estimator yang efisien dan konsisten dari parameter yang sebenarnya. Sehingga jika memang seperti itu, maka seharusnya tidak ada perbedaan sistematik antara kedua estimator. Jika terjadi perbedaan sistematik pada estimasi, maka asumsi dibalik estimasi itu dapat diragukan, misalnya asumsi bahwa ada efek khusus yang mempengaruhi NPM dan efek itu tidak berubah sepanjang waktu. Jika asumsi ini diragukan maka analisa data tidak tepat dilakukan dengan menggunakan pendekatan fixed effect karena asumsi fixed effect diragukan.

Tabel 14

Hausman Test Spesifikasi 1 dari Tabel 12 dan 13

\begin{tabular}{|c|c|c|c|c|}
\hline & \multicolumn{2}{|c|}{ Coefficients } & \multirow[b]{2}{*}{$(b-B)$} & \multirow{3}{*}{$\begin{array}{c}\text { sqrt }\left(\text { diag }\left(V_{-} b-V_{-} B\right)\right. \\
\text { S.E. }\end{array}$} \\
\hline & (b) & (B) & & \\
\hline & fixed & . & Difference & \\
\hline inout_lag & 23.17872 & 22.77475 & .403965 & .8791962 \\
\hline debt_asset 0 & -.3839801 & -.3865633 & .0025832 & .0871622 \\
\hline $\mathrm{kp}$ & $1.20 \mathrm{e}-12$ & $1.20 \mathrm{e}-12$ & $-2.49 e-15$ & $2.05 e-13$ \\
\hline$v p$ & $2.39 \mathrm{e}-09$ & $2.27 \mathrm{e}-09$ & $1.18 \mathrm{e}-10$ & $3.08 \mathrm{e}-10$ \\
\hline
\end{tabular}

Sumber: Perhitungan Penulis

Tabel 14 diartikan sebagai berikut, $\mathrm{b}=$ konsisten pada Ho dan Ha; $\mathrm{B}=$ tidak konsisten pada Ha, efisien pada Ho. Tes hipotesa yang diambil adalah Ho: perbedaan pada koefisien tidak sistematik. Dari hasil pada Tabel 14, dapat dihitung $\chi 2$ sebagai $\chi 2(2)=$ $(b-B)^{\prime}\left[\left(V \_b-V \_B\right)^{\wedge}(-1)\right](b-B)=0.21$. Sedangkan, Prob $>\chi 2=0.8993$. Artinya V_b-V_B adalah bukan positive definite). Pada spesifikasi ini, hipotesa yang diangkat adalah bahwa efek tingkat individu (individual-level effects) yang cukup digambarkan lewat random-effects model itu diterima. Selanjutnya, penelitian ini melakukan Hausman Test spesifikasi (2) dari Tabel 12 dan 13. Tabel 15 di bawah ini menghadirkan hasil tes tersebut. Sebagaimana dijelaskan sebelumnya, pemilihan antara pendekatan fixed effect dan random effect sangat diperlukan untuk mendapatkan estimator yang konsisten dan efisien sehingga untuk melakukan pemilihan, Hausman test dilakukan. Dari hasil di atas, dapat dihitung nilai $\chi 2$ dari $\chi 2(3)=(b-$ B) ${ }^{\prime}\left[\left(\mathrm{V} \_b-V \_B\right)^{\wedge}(-1)\right](b-B)=6.05$ dan Prob $>$ chi2 $=0.1090$, yang artinya adalah $V \_b-V \_B$ bukan positive definite sehingga model random effects diterima. Untuk hasil dari Hausman Test spesifikasi (3) dari Tabel 12 dan 13 dapat dilihat pada Tabel 16 di bawah ini.

Dari hasil di atas, dapat dihitung nilai $\chi 2$ dari $\chi 2(3)=(b-B)^{\prime}\left[\left(V_{-} b-V_{-} B\right)^{\wedge}(-1)\right](b-B)=$ 10.46 dan Prob $>$ chi2 $=0.0151$. Hasil ini menyimpulkan bahwa model random effect tidak diterma, sehingga untuk spesifikasi (3) lebih tepat dijelaskan dengan pendekatan fixed effect. Sehingga hasil analisa yang ada pada penelitian ini menunjukkan bahwa model dengan mengontrol variabel makro akan lebih tepat menggunakan pendekatan fixed effect. Isu terakhir yang perlu diinvestigasi adalah untuk melihat apakah kinerja keuangan pada periode sebelumnya mempengaruhi status eksistensi saham pada saat ini. 


\section{Tabel 15}

Hausman Test Spesifikasi (2) tabel 11 dan 12

\begin{tabular}{|c|c|c|c|c|}
\hline & \multicolumn{2}{|c|}{ Coefficients } & \multirow{3}{*}{$\begin{array}{c}(b-B) \\
\text { Difference }\end{array}$} & \multirow{3}{*}{$\begin{array}{c}\operatorname{sqrt}\left(\operatorname{diag}\left(V_{-} b-V_{-} B\right)\right) \\
\text { S.E. }\end{array}$} \\
\hline & (b) & (B) & & \\
\hline & fixed & . & & \\
\hline inout_lag & 26.8682 & 23.45167 & 3.416532 & 1.78685 \\
\hline debt_asset 0 & -.6172076 & -.3527619 & -.2644457 & .3213647 \\
\hline $\mathrm{kp}$ & $9.90 \mathrm{e}-13$ & $1.19 \mathrm{e}-12$ & $-1.96 e-13$ & $8.12 e-13$ \\
\hline$v p$ & $3.05 e-09$ & $2.43 e-09$ & $6.23 e-10$ & $8.37 e-10$ \\
\hline log_asset & -50.69373 & -3.529226 & -47.1645 & 23.4244 \\
\hline
\end{tabular}

Sumber: Perhitungan Penulis

Tabel 16

Hausman Test Spesifikasi (3) Tabel 11 dan 12

\begin{tabular}{|c|c|c|c|c|}
\hline & \multicolumn{2}{|c|}{ Coefficients } & \multirow[b]{2}{*}{$(b-B)$} & \multirow{3}{*}{$\begin{array}{c}\text { sqrt (diag (V_b-V_B }) \\
\text { S.E. }\end{array}$} \\
\hline & (b) & (B) & & \\
\hline & fixed & . & Difference & \\
\hline inout_lag & 26.20525 & 23.17872 & 3.026536 & 1.712755 \\
\hline debt_asset o & -.2109466 & -.3839801 & .1730334 & .3226608 \\
\hline $\mathrm{kp}$ & $1.51 \mathrm{e}-12$ & $1.20 \mathrm{e}-12$ & $3.08 e-13$ & $8.16 e-13$ \\
\hline$v p$ & $3.02 \mathrm{e}-09$ & $2.39 e-09$ & $6.34 \mathrm{e}-10$ & $8.14 \mathrm{e}-10$ \\
\hline$p d b$ & -.0012402 & $4.14 e-06$ & -.0012443 & .0004111 \\
\hline
\end{tabular}

Sumber: Perhitungan Penulis

Tabel 17 menghadirkan hasil regresi logistik dengan variabel dependen adalah inout dan variabel independen adalah kinerja keuangan dengan mengontrol variabel pasar, volume perdagangan. Hasil ini menunjukkan bahwa semua variabel masa lampau, yaitu periode sebelumnya tidak memiliki pengaruh signifikan terhadap variabel inout. Bahkan variabel volume perdagangan yang sebelumnya memiliki pengaruh signifikan, kini tidak memiliki pengaruh itu.

\section{Tabel 17}

In-out Model dengan Kinerja Keuangan Periode Sebelumnya

\begin{tabular}{llc}
\hline \hline Variables & $\begin{array}{c}(\mathbf{1}) \\
\text { inout }\end{array}$ & $\begin{array}{c}(\mathbf{2}) \\
\text { lnsig2u }\end{array}$ \\
\hline dar_lag & -0.01 & \\
& $(0.00)$ & \\
npm_lag & 0.01 &
\end{tabular}

\begin{tabular}{lll} 
& $(0.01)$ & \\
asset_lag & 0.00 & \\
& $(0.00)$ & \\
vp & -0.00 & \\
& $(0.00)$ & \\
Constant & $-1.92^{* * *}$ & -15.39 \\
& $(0.48)$ & $(858.31)$ \\
Observations & 81 & 81 \\
Number of stockid & 13 & 13 \\
\hline
\end{tabular}

Standard errors in parentheses ${ }^{* * *} \mathrm{p}<0.01,{ }^{* *} \mathrm{p}<0.05,{ }^{*} \mathrm{p}<0.1$

Sumber: Perhitungan Penulis

\section{SIMPULAN DAN SARAN}

Penelitian ini mengangkat isu terkait kekuatan status saham di LQ45 index dalam mempengaruhi kinerja keuangan khususnya profitabilitas perusahaan. Kinerja profitabilitas yang diukur adalah Net Profit Margin atau NPM. Terbatasnya literatur yang membahas mengenai saham-saham yang ter- 
daftar pada indeks saham blue-chips mendorong penelitian ini untuk dilakukan. Bahkan sepengetahuan penulis, literatur yang membahas status saham di indeks saham blue-chips seperti LQ 45, DJIA, S\&P 500, S\&P 400, Nasdaq 100, Russell 2000 ETFs hanya penelitian yang dilakukan oleh Prasetya dan Tasik (2017) yang membahas faktor-faktor yang mempengaruhi status masuk-keluarnya saham di LQ45.

Studi ini menggunakan status tersebut untuk menilai apakah status tersebut dapat mempengaruhi kinerja keuangan perusahaan. Hasil dari penelitian ini menunjukkan bahwa status masuk-keluar saham di LQ45 pada periode sebelumnya, di-proxi oleh variabel inout_lag ternyata mempengaruhi secara signifikan dengan magnitude berkisar 22,77 sampai 26,87 poin. Artinya, sahamsaham yang berada di LQ45 memiliki NPM sebesar 22,77 sampai 26,87 poin lebih besar dari saham-saham yang ada di luar LQ45. Pengaruh yang signifikan ini konsisten di hampir semua spesifikasi yang digunakan pada studi ini baik dengan menggunakan model regressi data panel, pendekatan fixed effect maupun pendekatan random effect.

Dengan menggunakan pendekatan fixed effect, magnitude dari inout 11 persen lebih besar dari tanpa pendekatan fixed effect. Setelah melakukan Hausman test, studi ini menemukan bahwa pada variabel makro dimasukkan sebagai variabel kontrol, asumsi pada pendekatan random effect ditolak sehingga yang diterima adalah pendekatan fixed effect. Namun, saat variabel makro tidak dikontrol, pendekatan random effect diterima.

Hasil dari penelitian ini menyarankan bahwa secara psikologis keberadaan saham di indeks LQ45 sangat mempengaruhi kinerja keuangan perusahaan meskipun saham-saham yang tidak berada di LQ45 yang diambil sebagi sampel penelitian ini bukanlah saham-saham murahan melainkan saham-saham yang juga pernah masuk di indeks LQ45 atau bahkan baru saja keluar dari indeks LQ45. Ternyata banyak hal yang terjadi sehingga nampak perbedaan yang mencolok antara saham-saham yang berada di LQ45 dan saham-saham yang berada di luar LQ45. Meski begitu, investigasi ini akan lebih baik jika ada penelitian-penelitian yang mencoba menggali dampak dari status saham di indeks LQ45 terhadap indikatorindikator keuangan yang lain untuk memperkaya literatur dan memperkuat argumen mengenai pengaruh status saham di LQ45 terhadap kinerja keuangan. Satu hal yang menarik untuk dilakukan adalah dengan mengganti NPM dengan indikator profitabilitas yang lain seperti ROA, ROE, dan sebagainya. Selain itu investigasi dapat dilakukan dengan menggunakan indikator keuangan yang lain seperti indikator likuiditas yang merupakan salah satu persyaratan di dalam indeks saham blue-chips. Juga, tidak menutup kemungkinan munculnya pola status saat investigasi dilakukan berdasarkan sektor saham.

\section{DAFTAR PUSTAKA}

Annaert, J., F. Buelens, L. Cuyvers, M. De Ceuster, dan M. Deloof. 2011. Are blue chip stock market indices good proxies for all-shares market indices? The case of the Brussels Stock Exchange. Financial History Review 18(03): 277-308. December 2011. DOI: 10.1017/ S0968565011000 187.

Antou, R. R. dan H. Tasik. 2017. Analisis Spillover pada Saham yang Masuk di Indeks LQ45 dan Non LQ45. Jurnal Emba 5(3): 2713-2720.

Bromels, J. 2018. The Fall of a Blue Chip: General Electric's Horrible 2018: The Industrial Giant's Year Began Poorly and Only Got Worse from There. Published on Dec 10, 2018 at 6:17AM. Accessed on Aug 16, 2019. https:// www.fool.com/investing/2018/12/10/ the-fall-of-a-blue-chip-general-electricshorrible.aspx.

Carrion, A. 2013. Very Fast Money: HighFrequency Trading on the NASDAQ. Journal of Financial Markets 16(4): 680711. doi:10.1016/j.finmar. 2013.06.005. 
Chung, D. Y. dan K. Hrazdil. 2010. Liquidity and Market Efficiency: Analysis of NASDAQ Firms. Global Finance Journal 21(3): 262-274. doi:10.1016/j.gfj.2010.09. 004.

Chung, M. M. C., K. C. Han, dan M. K. S. Tse, 1996. Interrelationship Among the Price Indexes of the NYSE, AMEX, and OTC. International Review of Economics and Finance 5(1): 63-75. doi:10.1016/s10590560(96)90006-4.

Dang, V. A., D. Michayluk, dan T. P. Pham. 2018. The curious case of changes in trading dynamics: When firms switch from NYSE to NASDAQ. Journal of Financial Markets. doi:10.1016/ j.finmar. 2018.07.001.

Danial, K. 2019. Cryptocurrency Investing for Dummies. ISBN 13: 978-1-119-533054, For Dummies Publisher, first edition (March 6, 2019).

Demsetz, H., 1997. Limit Orders and the Alleged Nasdaq Collusion. Journal of Financial Economics 45: 91-95.

Goff, D. C. 1994. The Relationship Among Firm Size, E/P, and Share Price Anomalies: NASDAQ Stocks Versus NYSE and AMEX Stocks. Journal of Economics and Finance 18(3): 287-299. doi:10.1007/bf02920488.

Guedes, E., A. Dionísio, P. J. Ferreira, dan G. F. Zebende. 2017. DCCA CrossCorrelation in Blue-Chips Companies: A View of the 2008 Financial Crisis in the Eurozone, Physica A 479 (2017) 38-47.

Hausman, J. A. 1978. Specification Tests in Econometrics. Econometrica 46: 12511271.

IDX. 2018. IDX Fact Book 2018. Research and Development Division, Indonesia Stock Exchange, diakses pada 21 Agustus 2019 melalui laman https://www.idx.co.id/ media/4648/20181218_fb-2018.pdf.

Ivanov, S. I., F. J. Jones, dan J. K. Zaima. 2013. Analysis of DJIA, SEP 500, SEP 400, NASDAQ 100 and Russell 2000 ETFs and their influence on price discovery. Global Finance Journal 24(3): 171-187. doi: 10.1016/j.gfj.2013.10.005.
Jogiyanto. 2010, Portfolio Theory and Investment Analysis, Gajah Mada Press, Yogyakarta.

Kandel, E. dan L. M. Marx. 1997. Nasdaq Market Structure and Spread Patterns. Journal of Financial Economics 45(1): 61-89. doi:10.1016/s0304-405x(96)00894$x$.

Malkiel, B. G. 2019. A Random Walk Down Wall Street: The Time-Tested Strategy for Successful Investing, W. W. Norton and Company, edition 12, ISBN 10:1324002182, ISBN 13:9781324002185.

Miller, M. B. 2018. Quantitative Financial Risk Management, Wiley Finance Series, ISBN 13:9781119522201，ISBN:1119522 20X.

Poon, A. 2016. Not Too Big To Fail: 5 Blue Chip Companies That Have Fallen From Grace: 5 Companies that are Good Reminders for Us that Blue Chip Companies are not Infallible. Online on September 27, 2016. Accessed on Aug 16, 2019. https://dollarsandsense.sg/nosuch-thing-as-too-big-to-fail-5-bluechipcompanies-that-have-fallenfromgrace/.

Prasetya, A. H. dan H. H. D. Tasik. 2017. Analisis Dampak Variabel Keuangan Saham Terhadap Keluar - Masuknya Saham di LQ-45 (Periode 2014 - 2015). Jurnal Emba 5(2): 1532 -1541.

Schwert, G. W. 1997. Symposium on market microstructure: Focus on Nasdaq. Journal of Financial Economics 45(1): 3-8. doi:10.1016/s0304-405x(97)00014-7

Srivastava, U. Dan Sheikh, R. A. 2016. Stock performance analysis of top ten Indian blue chip companies. International Journal of Commerce and Management Research 2(11): 29-30.

Suryani, A dan Herianti, E. 2015. The Analysis of Risk Adjusted Return Portfolio Performance Share for LQ 45 Index in Indonesia Stock Exchange in 2010-2014 Periods. Procedia - Social and Behavioral Sciences. Volume 211, 25 November 2015, Pages 634-643, https:/ / doi.org/10.1016/j.sbspro.2015.11.087 
94 Ekuitas: Jurnal Ekonomi dan Keuangan - Volume 3, Nomor 1, Maret 2019: 72 - 94

Tandelilin, E. 2010. Portofolio dan Investasi Teori dan Aplikasi. Edisi pertama. Kanisius. Yogyakarta.

Waller, R dan Wright, C. 2019. How to Invest in Real Estate: The perfect beginner's guide to creating wealth and passive income without making mistakes. Amazon kindle. ISBN:1095634380 ; 978109563438 